\title{
TERRITORIAL IMPACTS OF SEA-LEVEL RISE IN MARSH ENVIRONMENTS. THE CASE OF THE BAY OF CÁDIZ, SPAIN
}

\author{
FRANCISCO J. VÁZQUEZ PINILLOS ${ }^{1 *}$, MANUEL J. MARCHENA GÓMEZ ${ }^{2}$ \\ ${ }^{1}$ Departamento de Historia, Geografía y Filosofía. Universidad de Cádiz, \\ Plaza de España, 9, 11006 Cádiz, Spain. \\ ${ }^{2}$ Departamento de Geografía Física y Análisis Geográfico Regional. Universidad de Sevilla, \\ C/ Doña María de Padilla, s/n, 41004 Sevilla, Spain.
}

\begin{abstract}
How can sea-level rise affect territory? Has territorial planning adjusted to this new situation? This paper analyses the possible ramifications of changes in tidal recurrence over the course of this century in a potentially vulnerable marsh environment, such as the Bay of Cádiz, in southern Spain, where sea-level rise is already a fact. For that purpose, the regionalisation criterion is used as a basis for adjusting the magnitude of global problems to subregional scale. Geographic information systems are applied to portray the forecasted territorial changes according to the RCP4.5 and RCP8.5 scenarios presented by the Intergovernmental Panel on Climate Change (IPCC) for the years 2050 and 2100. Projections of sea-level rise show that the tide is travelling farther inland, not just invading unoccupied areas of marshes and beaches but also reaching urban and productive areas. Estimates indicate that the floodable area could expand by more than $20 \%$ in 2050 , with a further 2,000 ha of flooded areas added in 2100 for either of the two scenarios used. The occurrence of these changes, regardless of the model used, would therefore entail an alteration of the environmental, social, cultural and economic values and elements of the Bay of Cádiz, with the Natural Park being the most affected area. In response to these consequences, the need to apply the resulting projections to other variables is insisted on, with a view to introducing territorial management tailored to this new and already present reality. Application of the regionalisation criterion to study repercussions of the climate crisis in the Bay of Cádiz could serve as a precedent for the development of adaptation strategies in other marsh environments at subregional or local level.
\end{abstract}

\section{Impactos territoriales del ascenso del nivel del mar en entornos de marisma. El caso de la Bahía de Cádiz, España}

RESUMEN. ¿Cómo el ascenso del nivel del mar puede afectar al territorio? ¿Está la planificación territorial adaptada a esta nueva coyuntura? En este trabajo se analizan las implicaciones que podrían suponer los cambios en la recurrencia mareal a lo largo del presente siglo, sobre un entorno marismeño y potencialmente vulnerable como el de la Bahía de Cádiz, al sur de España, donde el ascenso del nivel del mar ya es un hecho. Para ello, se emplea el criterio de regionalización como base para ajustar la magnitud de los problemas globales a una escala subregional y la aplicación de los Sistemas de Información Geográfica para representar las alteraciones territoriales previstas según los escenarios RCP4.5 y RCP8.5 planteados por el Panel Intergubernamental del Cambio Climático (IPCC) para los años 2050 y 2100. Las proyecciones del ascenso del nivel del mar ilustran un incremento del espacio recorrido por la marea tierra adentro, invadiendo no solo zonas desocupadas de las marismas y las playas, sino también alcanzando las áreas urbanas y productivas. De acuerdo con las estimaciones, la superficie inundable se expandiría en más de un $20 \%$ en 2050 , y se sumarían 2.000 ha de zonas inundadas en 2100 para cualquiera de los dos escenarios empleados. Por tanto, la ocurrencia de estos cambios, con independencia del modelo utilizado, implicaría una alteración de los valores y elementos ambientales, sociales, culturales y económicos de la Bahía de 
Cádiz, siendo el Parque Natural el espacio más afectado. En respuesta a estas consecuencias, se insiste en la necesidad de implementar las proyecciones resultantes a otras variables de cara a la instauración de una gestión territorial adaptada a esta nueva -y ya presente- realidad. La aplicación del criterio de regionalización para el estudio de las repercusiones de la crisis climática en la Bahía de Cádiz, podría servir de precedente para la elaboración de estrategias de adaptación en otros entornos de marisma a escala subregional o local.

Key words: Climate change, sea-level rise, RCP, IPCC, territory.

Palabras clave: Cambio climático, subida del nivel del mar, RCP, IPCC, territorio.

Received: 24 February 2020

Accepted: 16 August 2020

* Corresponding author: F. J. Vázquez Pinillos. Departamento de Historia, Geografía y Filosofía. Universidad de Cádiz. Plaza de España, 9, 11006 Cádiz (España). E-mail: fj.vazquezpinillos@outlook.com

\section{Introduction}

The current global context cannot be defined without taking into account a climate situation that affects not only the environmental dimension but also the political, social and economic dynamics that govern the world's future (Le Roy Ladurie, 2017). This reality, concurrent with other social transformations, has been identified for several decades under the label of 'climate change'. However, given the urgent need to alleviate the effects already being manifested, that term has begun to be replaced by other concepts such as 'climate crisis' or 'climate emergency' (Fundéu, 2019). In any case, in this work the second expression mentioned has been employed, as it has been the most widely used in scientific literature in recent years.

The climate crisis started at the same time that the geological period of the Anthropocene began, both originating in human activities (Trischler, 2017). This new course in climate history began with the First Industrial Revolution, with the rise of factories, expansion of transportation and use of fossil fuels. This is when an incipient temperature rise in the troposphere can be glimpsed in the recorded data - the beginning of global warming, one of the key manifestations for understanding what is happening at present (Le Roy Ladurie, 2017; Valladares et al., 2019).

The concept of climate crisis is often used interchangeably to refer to both the causes and the consequences. The increase in greenhouse gas concentrations and the rise in mean sea-level, for example, are conceived as being parts of the same idea (Vineis et al., 2011; Pongiglione, 2012). In short, it is a complex reality in which the changes occurring in recent decades have been generated at a worrisome pace. For this reason, the climate crisis has become a paramount object of study in the area of scientific research and a political concern manifested by the development of strategies meant to both mitigate (moderating the scope of the causal factors) and adapt, with a view to reducing the impacts (ONU, 2015).

Noteworthy among the environmental impacts generated by the climate crisis are the expansion of desertification, more torrential rainfall, intensification of fires and loss of forest cover, changed ecosystems and the escalation of adverse weather events, as well as the increased frequency, height and intensity of storm surges (Karl et al., 2009; Banholzer et al., 2014; Huaico et al., 2018). The climate crisis also influences increased temperature in the oceans, where an acidification process is also occurring. Since this causes a decrease in the calcium carbonate that bivalve organisms feed on to build their shells, some components of marine ecosystems are thereby altered, such as the case of coral reefs (Clarcke et al., 2007). 
The territorial consequence about which there is more consensus is the rise of mean sea level resulting from the melting of glacial and polar ice masses, as well as the surface expansion of oceans, whose waters are gradually getting warmer year after year (Masson et al., 2018). The upper 75 metres of ocean masses became between 0.09 and 0.13 degrees warmer per decade between 1971 and 2010 (Church and White, 2011; Stocker et al., 2013). In the $20^{\text {th }}$ century mean sea level rose about $20 \mathrm{~cm}$. It is currently estimated that the ongoing trend doubles the rate observed in the last century (Spencer et al., 2015; Wigand et al., 2015). In any case, it is impossible for the mean sea level to rise more than two metres by the end of the century, as that is the maximum limit that could occur under the worst circumstances (Pfeffer et al., 2008). The process does not affect all coasts the same way, as other factors such as regional changes, winds, closeness of glaciers and vertical rock movement also have influence (FitzGerald et al., 2008; Karl et al., 2009).

Regarding the European continent, its location and geographical characteristics make it especially vulnerable with respect to the anticipated climatic changes. Global warming has been more vigorous in the middle latitudes of the northern hemisphere. In Europe there has accordingly been a thermal increase of $1.4^{\circ} \mathrm{C}$ compared to pre-industrial levels. Deaths associated to heat waves have also increased. The mean sea-level rise will also have serious consequences for the European coast, particularly in the Netherlands, where more than $50 \%$ of the country's territory has an altitude of less than 5 metres. In contrast, in other states such as Portugal, Spain or Turkey this percentage is between $0.5 \%$ and $1.5 \%$ (Bozhinova et al., 2014; Echavarren et al., 2019). These figures should obviously not be neglected since most of the population lives near the coast. Mean sea level will rise more than $40 \mathrm{~cm}$ along practically the entire coastline, except in the northernmost regions. It can therefore be expected (according to the outlined scenario) that by 2100 many beaches and urban complexes will have disappeared (Vousdoukas et al. 2020; Thiéblemont et al., 2019).

In this context, coastal areas can be considered the places most vulnerable to effects of the climate crisis, especially where the relief is very flat, as in the case of marshes. Moreover, in recent decades coastal areas have become the most changing, prosperous and vulnerable areas on the planet. Although there are differences in the extent of coastal occupation, the general trend suggests that this process continues to accelerate over time. As early as 2005 the FAO forecast that the population in coastal areas would double in the next 20 to 30 years (FAO, 2005). There is no doubt that the saturation of coastal zones implies increased exposure of the population and infrastructures to the threat of increasingly recurrent extreme events (Kulp and Strauss, 2019). In sum, the climate crisis does not just mean the appearance of new territorial dysfunctions but also the exacerbation of existing problems such as floods, saline intrusions, loss of coastal ecosystems and beach erosion (FitzGerald et al., 2008).

Under these terms, the subject matter considered in this paper is fundamental for understanding the behaviour of a phenomenon of such great interest, which has garnered a great deal of media and scientific attention and become one of the pillars of major political party agendas around the world (Paglia, 2018). The Intergovernmental Panel on Climate Change (IPCC), specifically encourages this type of local studies (which are rare in Spain) (Chica, 2010) to obtain more precise and reliable information about vulnerability by comparing past and present behaviour (Stocker et al., 2013). The lack of a climate crisis discourse in coastal areas as vulnerable as the one presented in this study makes manifest the urgent need to take note of the impacts occurring in this location and the dangers it must inevitably face in the future.

The main objective pursued by this paper consists of applying the regionalisation criterion to deduce the potential implications of a rise of mean sea level at subregional or local scale. In other words, global projections are adjusted so they can be used in the particular case of the Bay of Cádiz. As a secondary objective, it is proposed on the one hand to examine how far the implications of mean sealevel rise will be reflected in the Bay of Cádiz region throughout the 21 st century. On the other hand, it is considered to depict the incidence that mean sea-level rise will have by means of extrapolation models and techniques, so that territorial management policies can be developed beforehand. 


\section{Study area}

The research has been developed in the Bay of Cádiz region, situated at the southern end of the Iberian Peninsula in the Autonomous Community of Andalusia. Located in Cádiz province, this region comprises five municipal districts: Cádiz, Chiclana de la Frontera, El Puerto de Santa María, Puerto Real and San Fernando (Fig. 1).

It is an area very likely to undergo various territorial transformations resulting from this rise of mean sea level, given its geographic characteristics: a level and marshy space where land and sea merge, with the Bay of Cádiz Natural Park inserted among the region's five large cities (Benavente et al., 2015; Gómez, 2011). Ultimately, we find ourselves before an area of transition between land and water ecosystems, a singular landscape which is becoming increasingly fragile owing to anthropic pressure and the undeniable rise of mean sea level. According to the Preliminary Analysis of the Andalusian Coast's Vulnerability to Potential Sea-Level Rise Associated to Climate Change, the Bay of Cádiz is one of the regions most likely to suffer these changes (Méndez et al., 2011).

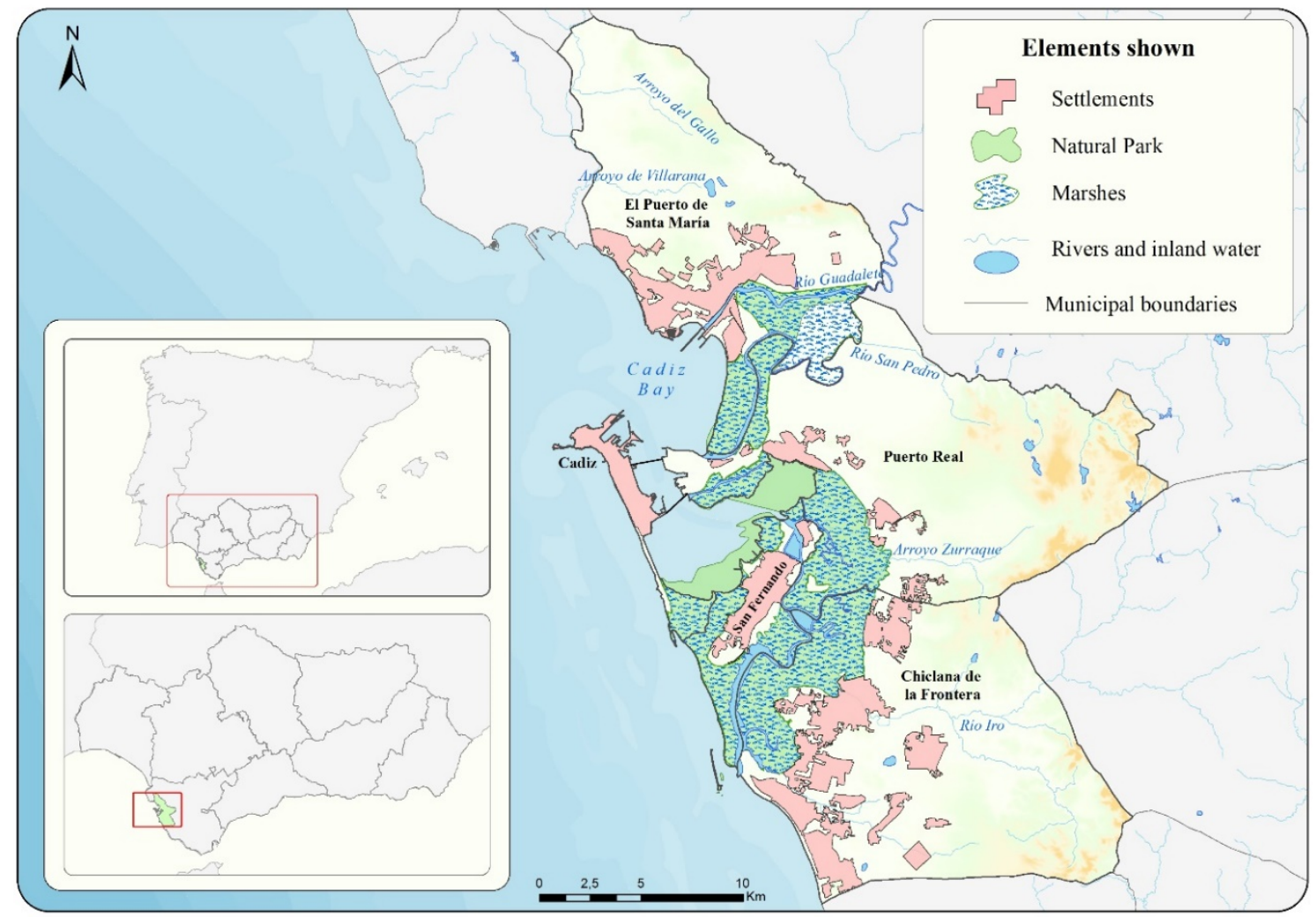

Figure 1. Location of the Bay of Cádiz region.

\section{Climate crisis and the Bay of Cádiz: two inseparable realities}

Available figures from tidal gauges close to the Bay of Cádiz prove that the rise of mean sea level is not a future estimate of a consequence of the climate crisis but rather a phenomenon that has been occurring for decades (Fig. 2). Since the early 1960s mean sea level has risen more than $20 \mathrm{~cm}$ in the Bay of Cádiz, around $3.5 \mathrm{~mm}$ annually, with reliability of $97.4 \%$. The fifth IPCC report forecast that this trend will increase over time, leading to progressive subsidence of coastal areas (Stocker et al., 2013). Mean sea-level rise in the Bay of Cádiz is the indicator that shows the most marked upward trend when compared to other variables whose behaviours are also seen to be changing with the current climate crisis, such as rising temperatures or lower precipitation (MAPAMA, 2016). 


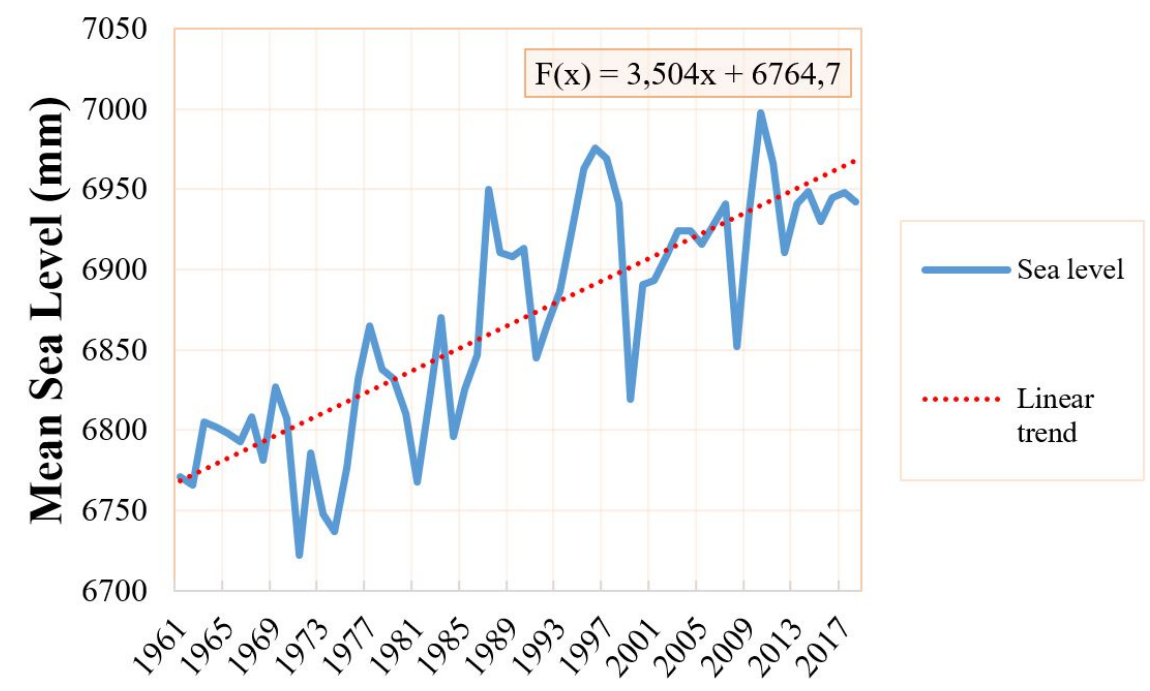

Figure 2. Evolution of mean sea level in the Bay of Cádiz (1961-2018).

The most well-known consequence is the increase in seawater flooding, an environmental problem that is already affecting various areas, such as some neighbourhoods in the municipality of Puerto Real, where every winter the streets are invaded by seawater due to storms. Moreover, these floods have worsened due to the higher number and intensity of extreme weather events also resulting from the climate crisis. On the other hand, the saline intrusions which will augmente by rising sea levels also generate worrisome impacts for the Puerto Real-Conil aquifer in the southernmost part of the region, which extends through the municipality of Chiclana and Puerto Real. This aquifer is in turn adversely affected by over-exploitation and pollution by fecal discharges due to poorly managed urbanization within city limits. The use of septic tanks has spread due to the absence of sewer systems, but they do not guarantee proper waste water treatment. The rise of mean sea level thus endangers water supply from the aquifer for the populations and agricultural sector of the Bay of Cádiz, a complex problem accentuated by the concurrently lower levels of precipitation (Chica and Barragán, 2011).

The rise of mean sea level and more storms also imply an increase in coastal erosion on Bay of Cádiz beaches, some of which are already experiencing dune regression. However, these conditions only reinforce the problems deriving from construction of breakwaters and dikes that constitute an obstacle for the proper functioning of littoral systems. The most worrisome case is the barrier spit of Valdelagrana in the municipality of El Puerto de Santa María, where the shoreline is receding around six metres per year, leading to loss affecting not just the beach but also the marshes forming part of the Natural Park (Benavente et al., 2015).

In any case, this new evolution threatens the Bay of Cádiz from various sides, beyond the direct impacts acting on natural or urban areas. The economy of the Bay of Cádiz depends on the coast and ultimately on the sea, owing to its lead role in most activities that take place, from traditional sectors such as salt collection or fishing to services. The intense exploitation of littoral resources along with uncontrolled urbanization has heightened the vulnerability and exposure of the Bay of Cádiz's populations to the threat from the current climate situation. The economic sectors most vulnerable to mean sea-level rise are aquaculture, whose facilities are situated in marshes that will undergo more tidal recurrence over time, and tourism, which is the main activity driving the local economy. A drop in sunand-sand tourism demand could occur due to water-supply problems, stronger climate conditions and, as is obvious, rising mean sea level and progressive regression of beaches (Méndez et al., 2011).

It is, therefore, clear that mean sea-level rise is the phenomenon that will cause the most damage: beaches and dunes will continue to recede as the sea invades. Extreme weather events (storms and floods) will intensify and become more frequent, even reaching areas well inland that were never 
previously threatened, and saline intrusions will augment. Also, the increased coastal vulnerability and exposure will entail serious impacts for the economy and it will become necessary to modify territorial plans.

The implications of the climate crisis on the Bay of Cádiz, which are occurring today, will predictably derive into much more alarming future alterations.

\section{Model and methodology}

This section focuses on building up projections for mean sea-level rise, given that it is the root of most of the territorial problems this area will face. For that purpose, the model put forward by the Fifth IPCC Report (2013), the latest issued to date, is used as reference. Most of the future estimates are based on studies by this body, as it is the most relevant in study of the climate crisis, although generally the model corresponding to the previous reports was used more assiduously, given that this latest one was published recently. There are different models presented by other experts, which show a considerably more pessimistic view, as in the forecasts of Pfeffer et al. (2008). Those authors indicate that over the course of the current century mean sea level will rise between $0.8 \mathrm{~m}$ and $2 \mathrm{~m}$ worldwide. Therefore, according to their studies, the most optimistic projection they put forward surpasses the most pessimistic index (RCP8.5) divulged by the IPCC, according to which a rise of $0.63 \mathrm{~m}$ is estimated. In any case, the projections of this paper are solely confined to the model from the last IPCC report.

Four scenarios are set out in the year 2013 report, known as representative concentration pathways (RCPs), indicating possible trends that will arise from greenhouse gas emissions in the $21^{\text {st }}$ century. This paper will discard two of those scenarios: RCP2.6, because it depicts an overly optimistic, even utopic, pathway; and RCP6.0, because it is the situation least considered in other studies. There is usually a tendency to use just one scenario, but in this case it was decided to approach the calculations by means of two of them (RCP4.5 and RCP8.5), the aim being to avoid presenting a biased view. Precise data is not handled, but rather complex estimates that can vary depending on the paths society takes as a whole. Therefore, by means of simultaneous use of a scenario wherein $\mathrm{CO}_{2}$ emissions would stabilize before 2100 (RCP4.5) and a pessimistic scenario of high greenhouse gas concentrations (RCP8.5), a most probable and accurate understanding of future events is obtained.

However the model bases its projections on global estimates for mean sea-level rise, i.e. it does not take into consideration spatial variability influenced by other regional factors (Karl et al., 2009). Thus, to understand the future behaviour of mean sea-level rise in a subregional context, the methodology put forward by Fraile et al. $(2013,2016,2018)$ was used. With this resource the flooding probability in each map cell is estimated, obtaining a more detailed result for cartographic depiction of the incidence of rising mean sea level. There are other methodologies for determining these changes (Titus and Richman, 2001; Gesch, 2009), though in most of them the result is presented dichotomously, i.e. identifying zones that would be affected by rising mean sea level and those that would not be harmed (Fraile et al., 2018).

The aim was accordingly to locate zones of the Bay of Cádiz that would end up below sea level and changes that would occur on the floodable surface, whose areas will also increase during this century. In this paper, the projections do not just refer to the year 2100 horizon (as put forward in the methodology used); they also apply to the year 2050. The procedures used are explained below in various phases.

The rise of mean sea level is a phenomenon marked by great spatial variability, so the figures indicated by the IPCC should not be used without considering local changes, which can differ substantially (Ministry of Agriculture, 2016). For that reason, in this first phase the local figure for sealevel rise is estimated for the selected horizons and scenarios. To analyse local sea-level rise the records of the Cádiz III tidal gauge were used, available in Permanent Service for Mean Sea Level (PSMSL, 
2019) and already used when analysing the evolution of mean sea level in the study context (Fig. 2). The database published by the Commonwealth Scientific and Industrial Research Organisation (CSIRO, 2013) was also used; it supplies information about changes in mean sea level worldwide up to the year 2013 (Fraile and Fernández, 2016). Calculation of the local value of sea-level rise is achieved using three variables, represented in the following equation:

$$
S L R=L x T+G
$$

Being SLR: local value of mean sea-level rise for a specific year and scenario; $L$ : difference between the global and local mean sea-level rise trend; $T$ : period that runs from data collection until year of projection; $G$ : global value for mean sea-level rise per the scenario used by the IPCC.

The difference between the global and local $(L)$ trends is obtained by linear regression of the data in the period available for both registers (Table 1). The results are more accurate because one of the Spanish tidal gauges with the longest time coverage is used. Regarding the global trend, the figures were updated to the year 2013 (last year for which there is information), with respect to those used by Fraile and Fernández (2016), who took data from 2011 as the last year of reference.

Table 1. Sea-level change trend in the tidal gauge Cádiz III

\begin{tabular}{cccc} 
Period observed & Local trend & Global trend & Difference \\
\hline $1961-2013$ & $3.72 \mathrm{~mm} /$ year & $2.14 \mathrm{~mm} /$ year & $1.58 \mathrm{~mm} /$ year \\
\hline
\end{tabular}

The result of the difference is subsequently multiplied by the number of years since the last date on which the IPCC projects were based (2005) until the horizon on which the mean sea-level rise is mean to be reflected (2050 and 2100). That is, $T$ equals 46 for the year 2050 and 96 for the year 2100 , considering that the start date is included in the calculation. Finally, the product of this multiplication is added to the predicted value for mean sea-level rise according to the estimates from scenarios RCP4.5 and RCP8.5 (Table 2).

Table 2. Forecasted mean sea-level rises according to the IPCC (measured in metres)

\begin{tabular}{cccc} 
Horizon & $\boldsymbol{T}$ & RCP4.5 & RCP8.5 \\
\hline 2050 & 46 & 0.26 & 0.3 \\
2100 & 96 & 0.47 & 0.63 \\
\hline
\end{tabular}

Next, in the second phase, the level of local flooding for both scenarios and horizons is estimated, with a probability of $50 \%$. The following formula is applied for that purpose:

$$
N i=N M M L+S L R+P L
$$

Being $N i$ : local flooding level; $N M M L$ : mean sea level with respect to the topographic zero of Alicante; $S L R$ : local mean sea-level rise value; $P L$ : local high tide.

Taking only NMML and SLR, the zones that would end up below $0 \mathrm{~m}$ sea level can be found, subtracting the value of the sum from the Digital Elevations Model (DEM), with a probability of 50\%. Both the calculation and the depiction of results used the MDE generated by the Andalusian Institute of 
Statistics and Cartography (IECA) between 2008 and 2009, which has a spatial resolution of 10 meters (IECA, 2008).

For local high tide $(P L)$, the highest tide from the latest data records of the State Ports (PE, 2019) was chosen. The value used corresponds to 19 March 2011 and coincides with the measurement used by Fraile et al. (2018), in accordance with the Earth's proximity to the Sun and the position of the heavenly bodies. The Bay of Cádiz is located in a mesotidal zone, whereby the influence of tides on the territory is quite significant, as can be seen in the total surface of current floodable zones. The three identified variables are set out in Table 3.

Table 3. Values for calculating local flooding level (measured in metres)

\begin{tabular}{ccccc} 
& \multicolumn{2}{c}{ RCP4.5 } & \multicolumn{2}{c}{ RCP8.5 } \\
\hline \multirow{3}{*}{ SLR } & 2050 & 2100 & 2050 & 2100 \\
& 0.33 & 0.62 & 0.37 & 0.78 \\
\hline \multicolumn{3}{c}{ NMML } & 0.17 \\
\cline { 2 - 4 } & PL & 1.72 \\
\hline
\end{tabular}

The cartographic representation will result from subtracting the value of the local flooding level (Ni) from the DEM for each year of the selected scenarios and years, using the software ArcMap. Thus, this third phase consists of modifying the DEM so that all of the cells with a value resulting as equal to or less than 0 metres will form part of the predictable flood zone, for a probability of $50 \%$. The results are shown in Table 4.

Table 4. Values for mean sea-level rise (measured in metres)

\begin{tabular}{ccc} 
Horizon & RCP4,5 & RCP8,5 \\
\hline 2050 & 2.22 & 2.26 \\
2100 & 2.51 & 2.67 \\
\hline
\end{tabular}

Now in this paper, as in the bibliography used, the aim has been to avoid the dichotomous depiction of results, where only the flooded cells are distinguished form those that would not be affected by the rise of mean sea level. Accordingly, places where flooding probability is under $50 \%$ would not be rejected. To estimate flooding probability three typical deviations were added to and subtracted from the values for mean sea-level rise (Fraile et al., 2013).

The model used for the projections of mean sea-level rise were subjected to some changes in this paper, which can be summarised as follows:

- The calculations were projected for both years 2100 and 2050;

- Given the conditions determined, zones which would end up below $0 \mathrm{~m}$ sea level and could become flooded areas were added;

- The expression of flood probability values follows a discrete distribution. It was decided to use this representation type because it is easier to manage and to graphically analyse the results. The 'high probability' category corresponds to cells whose likelihood of flooding is above $90 \%$; 'medium probability' is associated with values with a likelihood between $50 \%$ and $90 \%$; and 'low probability' indicates a likelihood under $50 \%$. 


\section{Results}

Next, the sea-level rise projections for 2050 and 2100 are presented, according to scenarios RCP4.5 and RCP8.5.

The application of cartographic tools on the mean sea-level rise projections enables prediction of the extent of future territorial changes that will affect the urban, economic and environmental systems. This is an exercise of regionalisation, wherein global climate crisis patterns have adjusted to the specific circumstances of the Bay of Cádiz.

The first conclusion drawn from viewing the maps is the evident danger facing the study area, for regardless of the scenario selected the consequences are clearly tangible. In second place, it could be expected that minor dissimilarities between the estimates from RCP4.5 and RCP 8.5 would deliver similar results. Unsurprisingly, a slight change in the mean sea-level rise projections proves to lead to totally different scenarios.

Figure 3 considers that fluctuations in mean sea level will have important incidence for the year 2050, even though those projections correspond to scenario RCP4.5. The flooded surface, understood to be that which would end up under seawater in the absence of the tidal factor, would increase considerably in size, occupying beaches and invading a large part of the marshes northeast of San Fernando and to the south near the settlement of Sancti Petri in Chiclana de la Frontera. The extent of areas that would be situated under $0 \mathrm{~m}$ sea level would approach 2,000 ha, although it must be borne in mind that a portion of it is already currently under that threshold (Table 5). Also, this analysis does not take into account eventual topographic barriers, natural or artificial, which prevent flooding of low inland zones. However these areas are generally situated close to the shore, whereby this problem has no influence. In any case, in the cartography they are shown as zones situated under $0 \mathrm{~m}$ sea level and not as flooded zones, to avoid confusion. With respect to floodable surface, it would increase by $20.44 \%$, albeit taking into account the entire probability percentage range. The zone with a high probability of becoming floodable is particularly situated between the Guadalete and San Pedro Rivers on the region's northern fringe.

For 2100, the most notable changes would occur in the zones situated under $0 \mathrm{~m}$ sea level, as can be seen at Trocadero Island (located in the westernmost part of the municipality of Puerto Real), almost all of which would end up under water. The extent of the floodable zones would increase by just over $7 \%$ compared the year 2050 , above all in the northernmost part of the map. The zones previously considered places with medium or low flooding probability would now become high-risk zones (Fig. 4). 


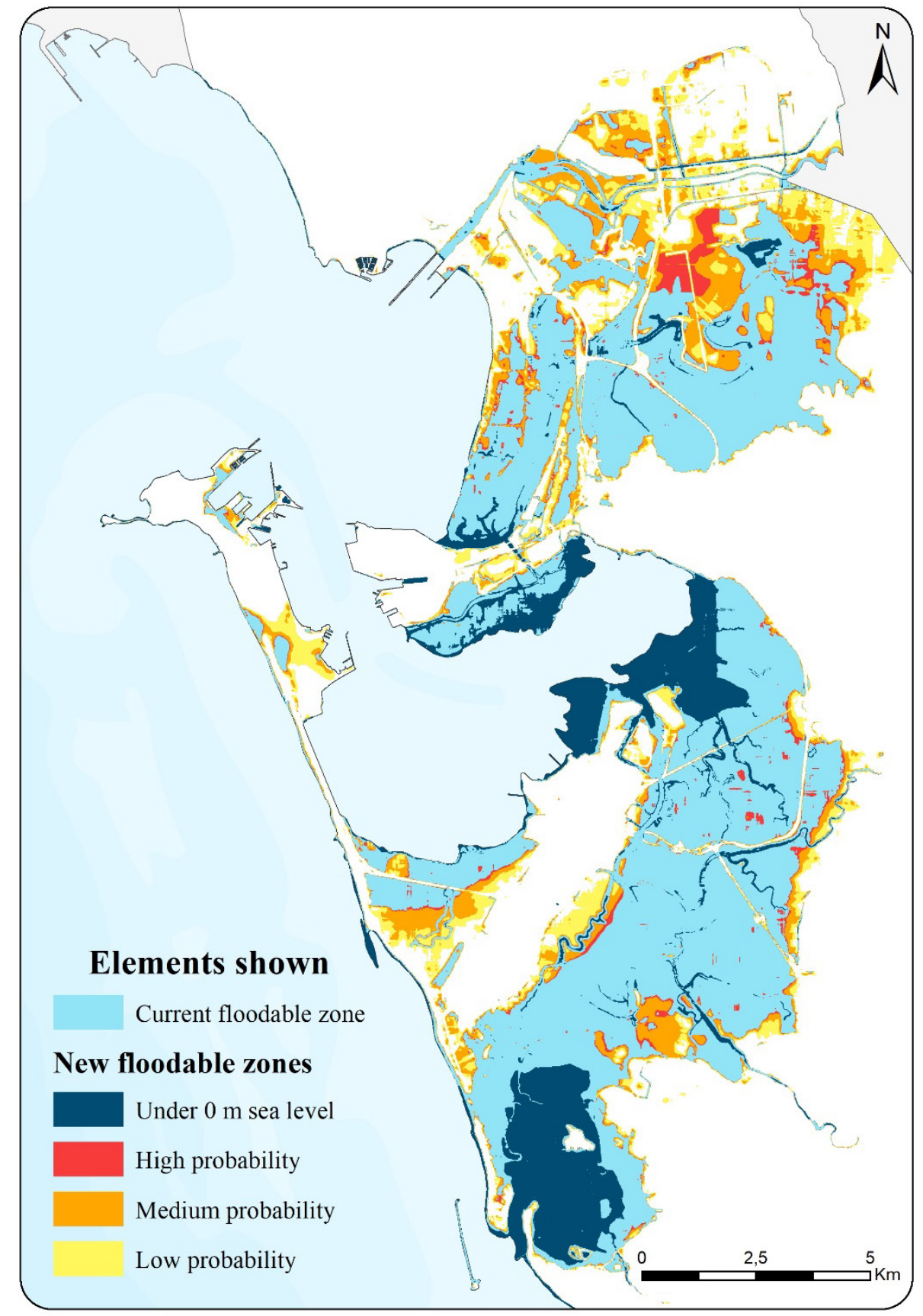

Figure 3. Mean sea-level rise projections according to IPCC scenario RCP4.5 for the year 2050.

Table 5. Changes in mean sea-level rise according to RCP4.5 (measured in hectares)

\begin{tabular}{cccccc}
\multirow{2}{*}{ RCP4.5 } & $<\mathbf{0}$ m sea & \multicolumn{3}{c}{ Floodable zone } & \multicolumn{2}{c}{ Total floodable } \\
\cline { 3 - 5 } & level & High probability & Medium probability & Low probability & 9157.75 \\
Present & 358.24 & & 9157.75 & 1507.06 & 11029.95 \\
$\mathbf{2 0 5 0}$ & 1985.21 & 7994.46 & 1528.43 & 1129.17 & 11694.78 \\
$\mathbf{2 1 0 0}$ & 2549.19 & 9084.37 & 1481.24 & \\
\hline
\end{tabular}




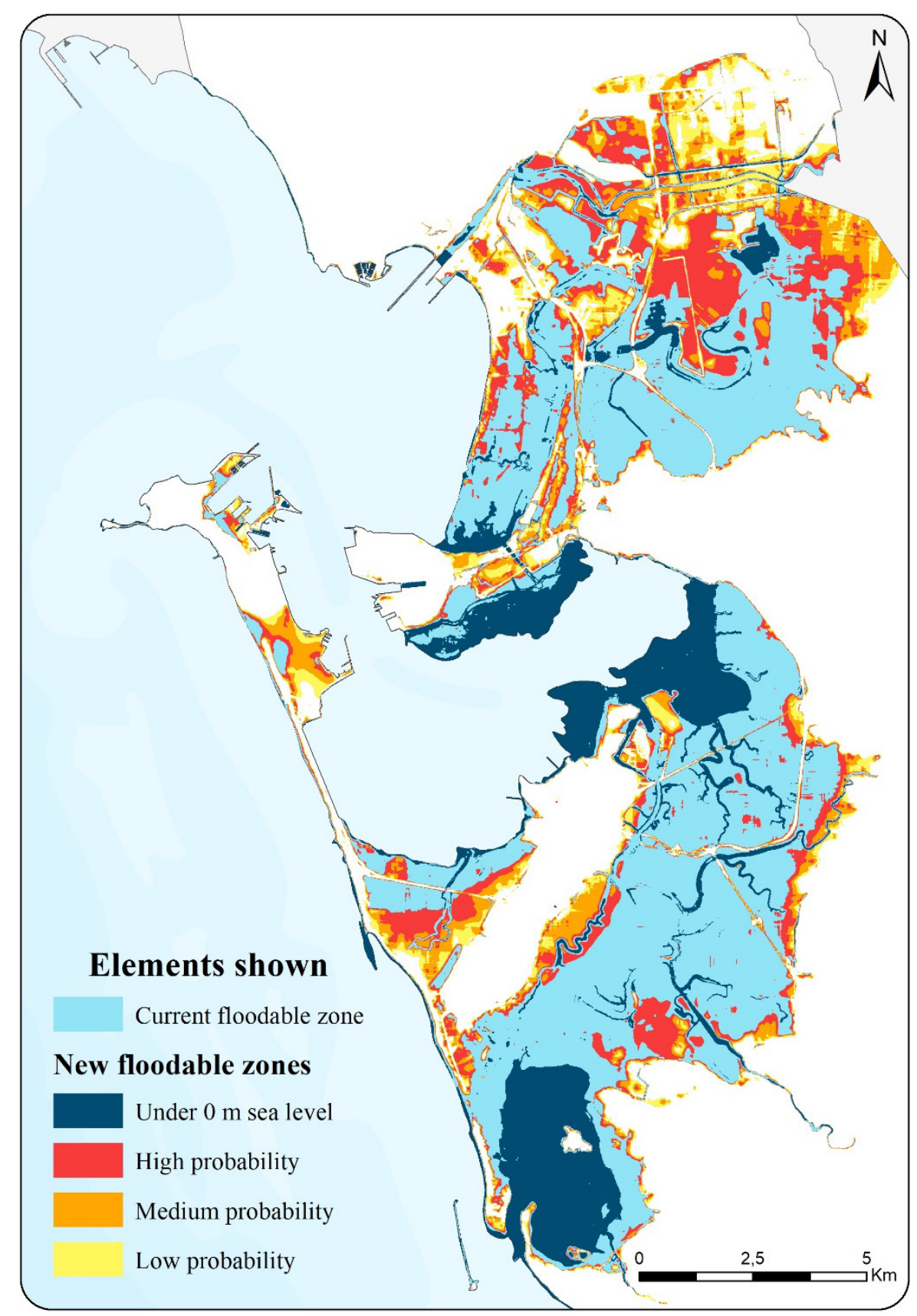

Figure 4. Mean sea-level rise projections according to IPCC scenario RCP4.5 for the year 2100.

As for scenario RCP8.5, it is striking that for 2050 a lower flooding probability with respect to RCP4.5 is indicated, though when only considering total floodable surface it can be seen that the number of hectares affected by mean sea-level rise in 2050 would be similar to what takes place in 2100 for scenario RCP4.5 (Fig. 5). This is because the typical deviation used for RCP8.5 is higher than that used in the other scenario. 


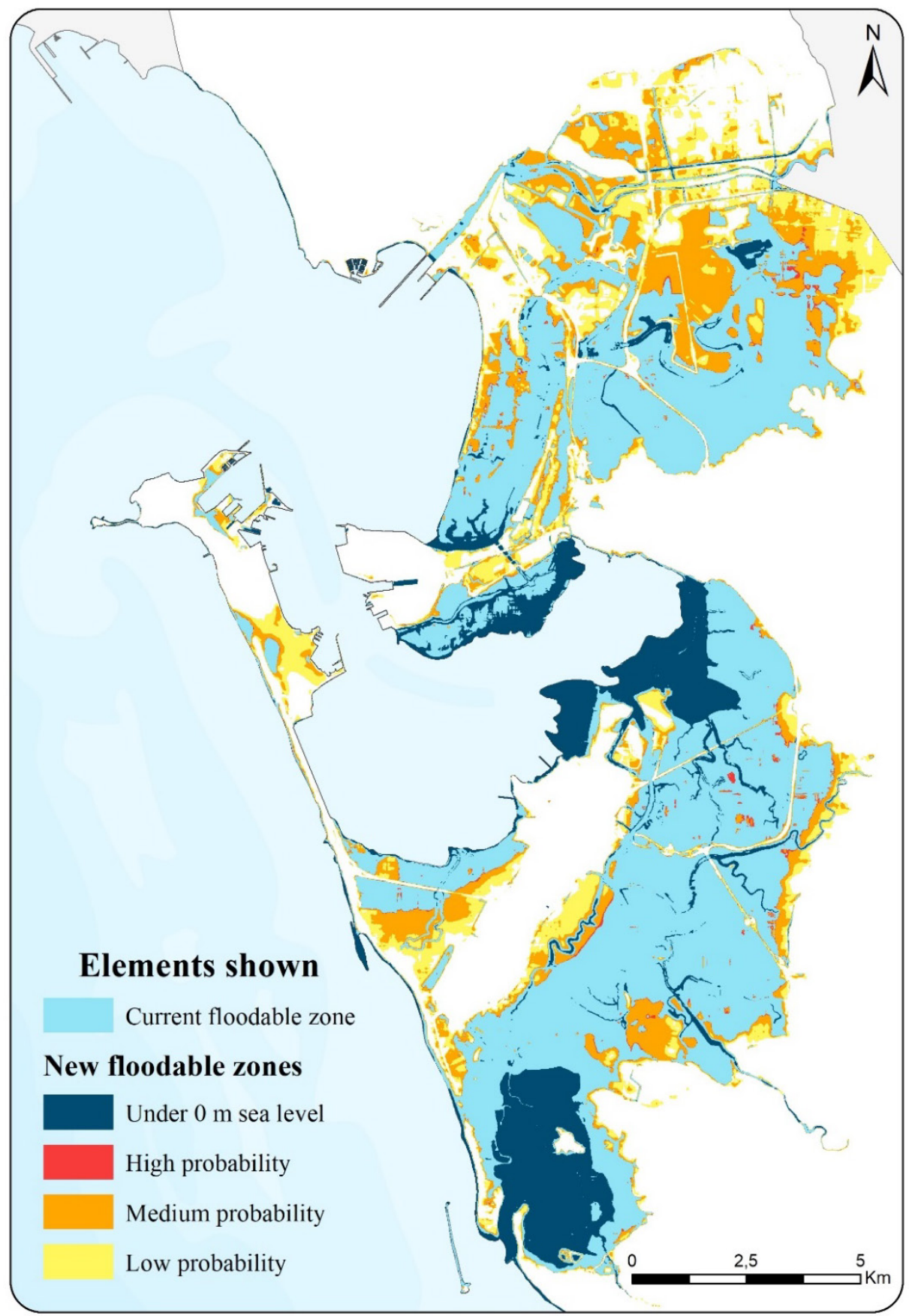

Figure 5. Mean sea-level rise projections according to IPCC scenario RCP8.5 for the year 2050.

Finally, if the most pessimistic circumstances according to the IPCC occur, at the end of the century the flooded surface would invade new areas inland from the marshes, seriously endangering some of the Bay's infrastructures. The floodable zones would grow even more and with high probability (Table 6), occupying marshland, protected spaces, agricultural zones and even some urban developments. If a high tide of this scale occurred, per the parameters of scenario RCP8.5 in the year 2100 there would be a serious problem connecting the region's five municipalities. This is even more damaging, bearing in mind that the relationships occurring in this scope are adjusted to a polycentric model. The links between Cádiz and San Fernando via the CA-33 and between Cádiz and Puerto Real via the CA-35 would be affected by the calculated mean sea-level rise and the selected high tide. The same would happen with the roads linking San Fernando and Chiclana, and between Puerto Real and El Puerto de Santa María (Fig. 6). 
Table 6. Changes in mean sea-level rise according to RCP8.5 (measured in hectares)

\begin{tabular}{cccccc}
\multirow{2}{*}{ RCP8.5 } & $\mathbf{<}$ m above & \multicolumn{3}{c}{ Floodable zone } & \multicolumn{2}{c}{ Total floodable } \\
\cline { 3 - 5 } & sea level & High probability & Medium probability & Low probability & 9157.75 \\
Present & 358.24 & & 9157.75 & 1823.44 & 11511.11 \\
$\mathbf{2 0 5 0}$ & 2062.12 & 7596.7 & 2090.97 & 1053.71 & 12043.95 \\
$\mathbf{2 1 0 0}$ & 2839.44 & 9257.84 & 1732.4 & \\
\hline
\end{tabular}

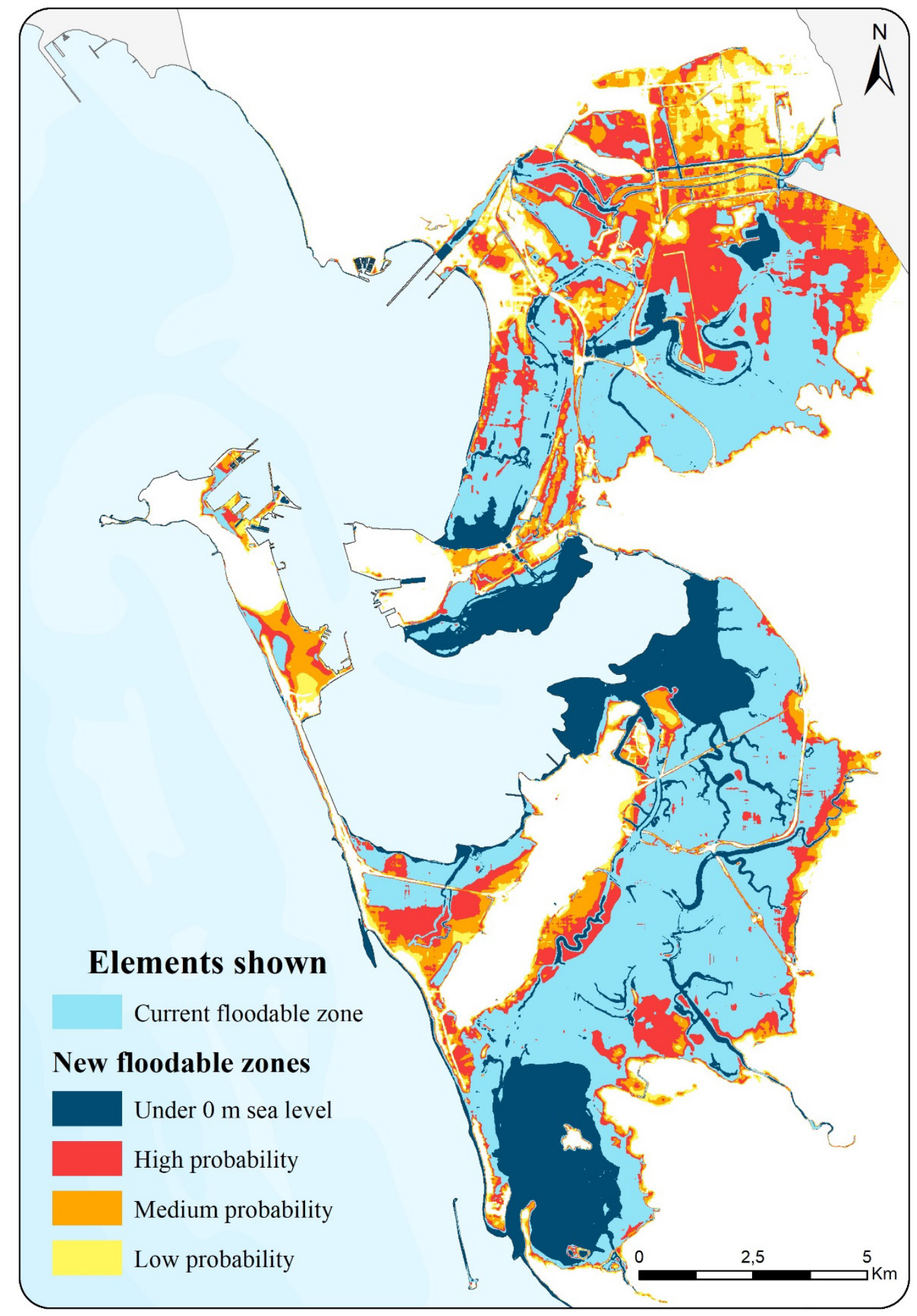

Figure 6. Mean sea-level rise projections according to IPCC scenario RCP8.5 for the year 2100. 
In short, the zones most likely to become flooded places during the $21^{\text {st }}$ century are the marshes of San Fernando and Chiclana (southern part of the region), Trocadero Island in Puerto Real and the southern end of the Valdelagrana barrier spit in El Puerto de Santa María, whose surface forms part of the Natural Park. With respect to floodable zones, the places most likely to suffer the invasion of tides expand over the region's five municipalities. In Cádiz, the most notable changes will occur on its beaches, docks and seafront promenade, as well as in urban developments and productive areas in the southernmost part of the municipality. In San Fernando, the marshes will lose part of their current surface and floodable zones will expand around the entire perimeter of the city as well as its beaches. In Chiclana it is forecast that the beach of Barrosa (the region's longest) will significantly recede and in the westernmost districts of the city the same problems already occurring in some neighbourhoods of this area may begin to be felt. In Puerto Real the most vulnerable zones are the southwest part of the municipality and the adjacent industrial poles along with the campus of the University of Cádiz. Finally, in El Puerto de Santa María the space on the left bank of the Guadalete River and the area close to the municipal limit of Jerez (northeast of the region) around Poblado de Doña Blanca will be the zones most affected by the rise of mean sea level.

Figure 7 shows the values grouped for each of the maps presented. The increase in the zones under $0 \mathrm{~m}$ sea level can clearly be seen and above all the areas with a high probability of becoming floodable.

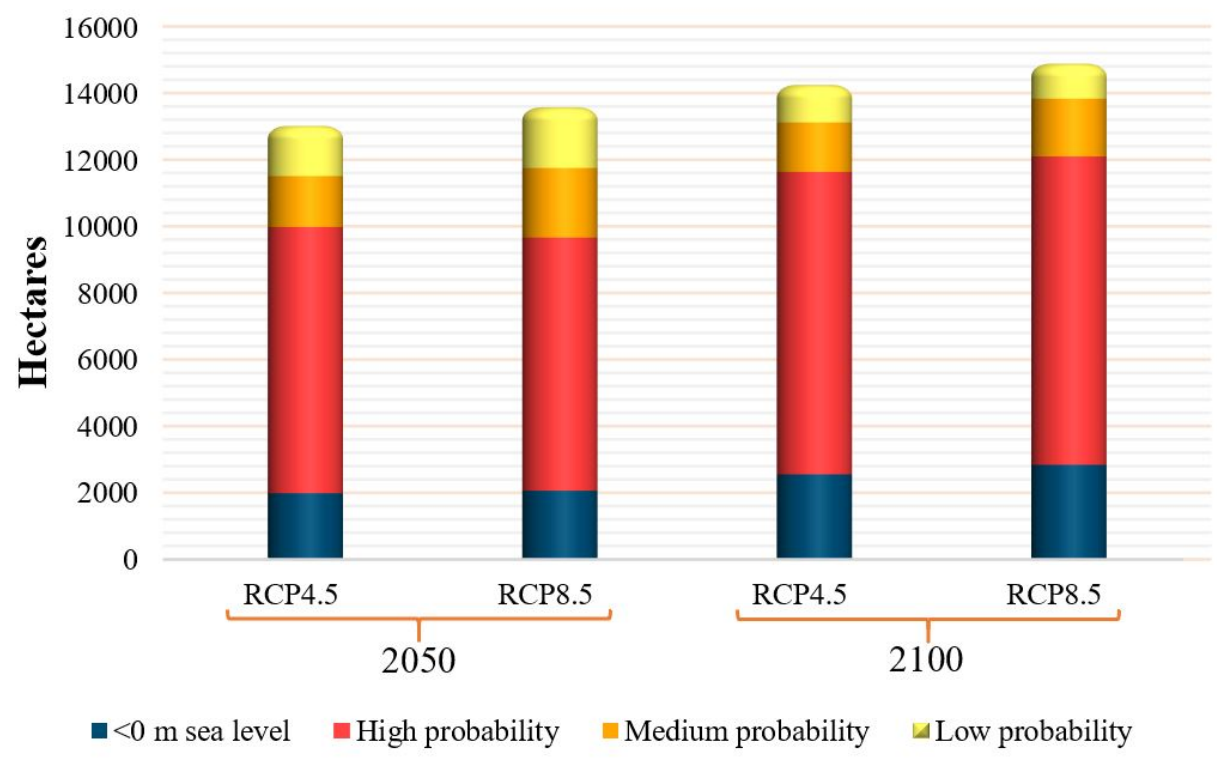

Figure 7. Changes in floodable surface of the Bay of Cádiz based on the maps.

On the other hand, the projections of mean sea-level rise may have utilities such as the study of their implications on property values (Fig. 8). Territorial planning, environmental resource management and urban planning should encourage studies about the vulnerability and exposure of assets of major environmental or cultural value in the face of upcoming changes. Scenario RCP4.5 was used because it is the one most coherent regarding current trends for rising $\mathrm{CO}_{2}$ emissions (Van Khanh, 2020). Among assets of cultural interest, several that are periodically invaded by tides because they are situated in the marshes stand out, such as salt-pond buildings. If the mean sea level continues to rise there will be more recurrent flooding and hence increased deterioration of the affected assets. It is interesting to consider how certain historical assets might not just be eroded by tidal flow but would also end up below sea level, such as the Fort of San Luis on Trocadero Island in the westernmost part of Puerto Real municipality. 

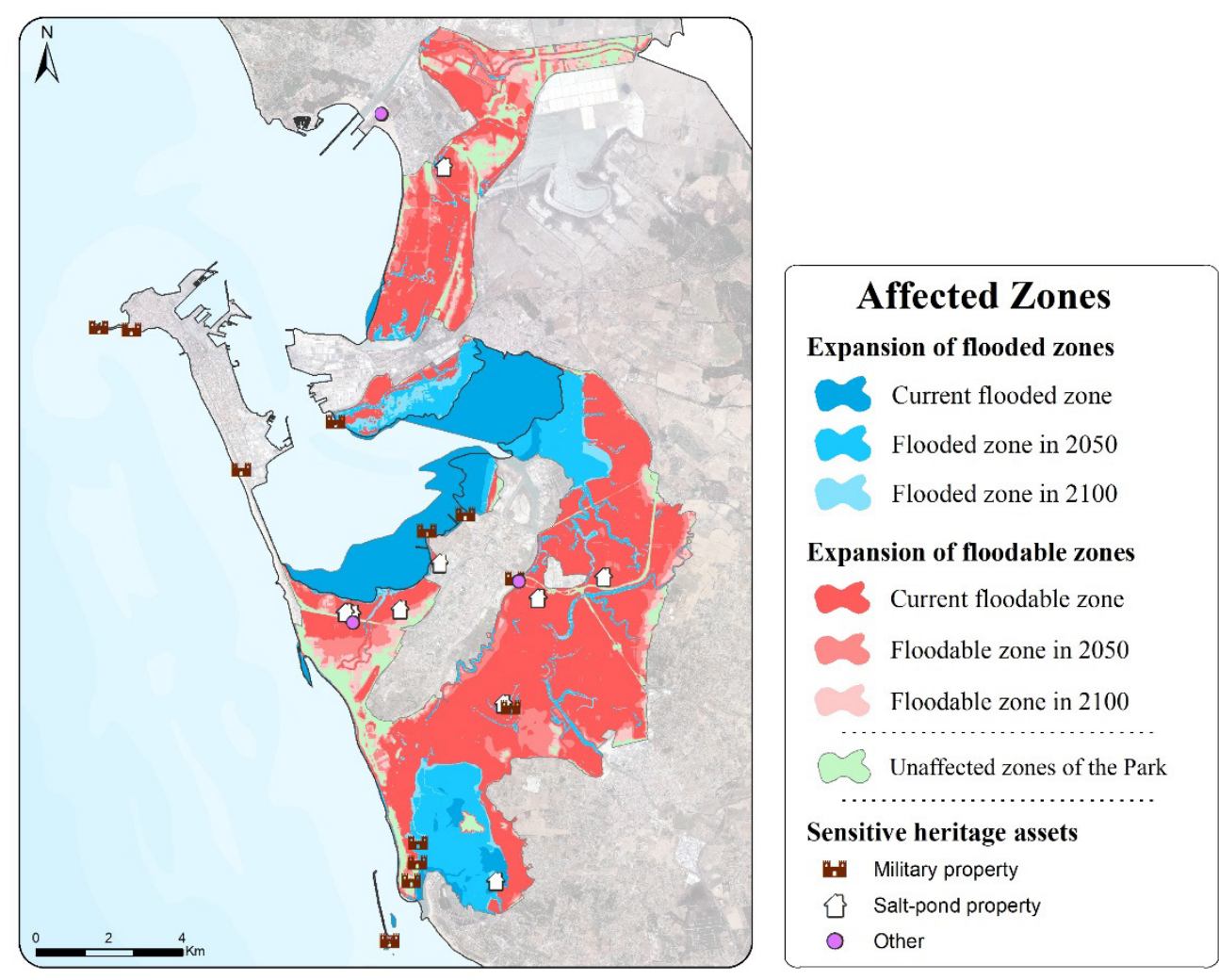

Figure 8. Implications of mean sea-level rise on the Natural Park and property assets of the Bay of Cádiz according to RCP4.5, for a probability above $90 \%$.

The Bay of Cádiz Natural Park is the element that will present a more considerable transformation due to its geographic features. The assets of cultural interest that will presumably be affected during the current century are also indicated. Only the most emblematic of the salt-pond buildings are shown. Most of these singular elements are abandoned, lack legal protection and are directly exposed to the rising mean sea level.

As for the Bay of Cádiz Natural Park, the sea depths and ecosystems it houses would deteriorate due to chemical and temperature changes of its waters, as already indicated, though also due to the rising mean sea level, which adversely affects some species used to dwelling in shallow waters. Some of the emerged surface of the park would end up under water in a not-too-distant future, with the resulting consequences for land-based life. The marshes' vegetation is distributed in bands from the shore inland, depending on tidal influence (Rendón, 2011). The accelerated expansion of floodable surface would hinder the ability of vegetation to adjust to variations in tidal periodicity and many species might consequently disappear (FOESA, 2013). The changes in flooded and floodable surface of the Natural Park are summarised in Figure 9. These graphs summarise the transformations seen in the previously shown maps, where an increase in zones situated under $0 \mathrm{~m}$ sea level is considered and a reduction of the surface unaffected by tidal recurrence. The estimates correspond to scenario RCP 4.5 for a probability above $90 \%$. 

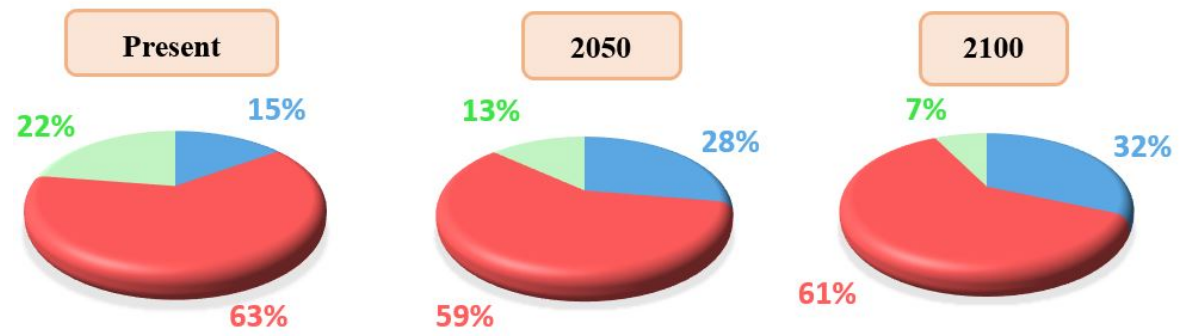

Flooded

Floodable

Not affected

Figure 9. Changes in the surface of the Bay of Cádiz Natural Park.

\section{Discussion}

Application of the regionalisation criterion allows for construction of a subregional cartography with much higher resolution than those used to represent the behaviour of climatic phenomena on a global scale, thereby facilitating the visualisation of spatial variability among the impacts on different land uses.

The studies on mean sea-level rise considered can be used to diagnose territorial impacts from many standpoints, which could be a subject of future papers. The imminence of the expected changes (see projections for the year 2050) should spur reworked planning in matters involving adaptation to and mitigation of the climate crisis, especially at subregional and local scale (Chica, 2010). The future changes to the physical environment projected in the previous section would hence imply inordinate costs for the government. However, if passivity is chosen instead of implementing new measures, then the economic consequences will be devastating (Rodríguez, 2015).

The projections described overlook the existence of other processes unleashing the climate crisis that will intensify as sea level rises, such as the increased frequency and energy of adverse weather phenomena, barometric oscillations, wave setup, wind setup and even increased devastation from an eventual tsunami, given that as mean sea level rises large waves will have fewer obstacles to keep them out of settled areas (FitzGerald et al., 2008; Benavente et al., 2019). Likewise, to improve the rigour of the analysis, it would be worthwhile to consider changes produced in the sedimentary budget caused by reservoir construction, coastal infrastructure, dredging or aggregate extraction (Hartig et al., 2002; Pranzini and Williams, 2013). If any of these variables were added to the parameters already analysed, the cartographic result would be very different. According to the maps, for flooding to happen the involvement of weather phenomena will not be necessary; only an exceptional tide will be needed.

It should nevertheless be stressed that the projections for the rise of mean sea level are made with a high degree of uncertainty, due to both speed with which the changes are manifesting and the concurrence of multiple factors that may condition the result. However, the broad temporal spectrum of available tidal gauge data, the use of two RCP models and probabilistic calculation reduce this imprecision (Fraile et al., 2018). Although in the scientific literature it is more common to use a dichotomous representation when mapping the effects of the rise of mean sea level, to show different future situations several models and time horizons are often resorted to. For example, Hartig et al. (2002) estimated projections of mean sea-level rise in the New York City's Jamaica Bay marsh areas by using five global climate scenarios for the years 2020, 2050, 2080, and 2090. Prado et al. (2019) applied a similar criterion for the mouth of the Ebro in Spain, though based on the RCP4.5 and RCP8.5 scenarios of the last IPCC report, which coincides with this investigation.

In general, the authors agree that predictions of mean sea-level rise should be reflected in cartography using the Geographic Information Systems, with ArcMap being the most recurrent software (Hartig et al., 2002; Bornman et al., 2016; Raw et al., 2020). Also, the projections tend to conform to the models disseminated by the IPCC, both those published by the Special Report in Emissions Scenarios (SRES) and the RCP. In other studies, it is preferable to extrapolate the data collected by local tidal gauges to compare them with global prediction models (Hartig et al., 2002). 
Compared to other tidal gauges around the world, a significantly higher growth is observed in the Bay of Cádiz. The $3.5 \mathrm{~mm}$ annual rise in mean sea level in this environment contrasts with, for example, the $2.7 \mathrm{~mm}$ recorded by Hartig et al. (2002) in New York in the USA or the $2.19 \mathrm{~mm}$ observed by Raw et al. (2020) in the Knysna estuary in South Africa. However, contrary to what might be expected, the result of the calculation in this research is slightly more optimistic than in the literature used (Fraile et al., 2018). Despite all this, most researchers who have worked on the analysis and projection of mean sea-level rise in marsh areas agree that such ecosystems are diminishing as temperatures rise. The balance of coastal wetlands depends on numerous factors (wave erosion, exposure to prevailing winds, accumulation of sediments, mean sea level); but if any of those elements are altered, the ecosystem will weaken (Reed, 2002; Craft et al., 2008).

The application of cartographic projections of mean sea-level rise to other variables can be an instrument for administration. This article proposed as an example to study the consequences this phenomenon would have on heritage properties situated near the coast. If the areas vulnerable to being invaded by water are known, then the uses, activities and heritage elements most prone to suffering the consequences of floods can be identified. On that basis, adaptation policies can be implemented with a view to correcting territorial dysfunctions ahead of the expected phenomena. Various instruments of international scope meant to promote the development of plans linked to the fight against climate crisis particularly insist on the need to use geographic information systems as a methodological support (ESRI, 2010; WHO, 2012). The project Climate Change Planning for Regional and Local Authorities can serve as an example of good practices for the application of mitigation and adaptation strategies to climate crisis at subregional or local level, where a structured model is proposed that would fulfill the role of guide during development of a plan (Marletto et al., 2012).

\section{Conclusions}

This paper considers the implications the climate crisis has had for the territory of the Bay of Cádiz, a region eminently vulnerable for two reasons: its latitude close to tropical regions, making it more fragile from the thermal and hydric standpoint; and its level topography and littoral position, leaving it relatively undefended before the rising mean sea level. There is no doubt that the coast is gradually receding, especially around the marshes of the Natural Park. It is disturbing to think that these changes, already tangible, are not being dealt with or taken into account when managing the area. Most economic activities continue to operate according to the same system, ignoring the current climate situation: the aquaculture and salt-pond infrastructures are more recurrently invaded every year; some of the industrial installations could end up situated in floodable zones during this century; tourism remains dependent on the existence of beaches; some urban developments have begun to suffer periodic flooding; and all this without speaking of the lack of economic adjustment to rising temperatures and lower precipitation.

To anticipate future events and avoid unfathomable costs, the development of projections is essential, especially for the changes already taking place. As has been considered, the scenario used does not matter; the current problems will continue to follow the same upward path, although the respective pace will vary depending on the initiatives applied against the climate crisis. It must be highlighted that the forecasts for mean sea-level rise only consider the future behaviour of an extraordinary high tide. Future research could develop studies about the evolution of the intensity and frequency of storms during the course of the $21^{\text {st }}$ century, whose appearances are ever more common owing to the climate crisis.

It must be insisted that projections of mean sea-level rise should not be expressed in an isolated manner, i.e. it is not enough just to describe the distribution of new floodable zones from the scope of the study; those territorial alterations have to be applied to other also spatial variables. It is important to make clear what consequences this new scenario could have on settlements, infrastructures, protected 
spaces, assets of environmental or cultural value, economic activities, ports and beaches, etc. Indeed, a territorial problem is occurring, wherein humanity is situated as the perpetrator, though also as the possible remedy if the commitment is global. Territorial planning is a crucial departure point for regulating the development of activities that avert the effects of climate crisis by favouring restoration of natural behaviours of the environment (Pissolito, 2019). The spatial deficiencies are currently widespread, present in each of the three systems on which territorial plans are usually based.

First of all, the economic system ignores the reality. Tourism projects are sustained by exploiting increasingly scarce water resources owing to the expansion of persistent drought. In second place, the urban system of the Bay of Cádiz was traditionally characterised by its disdain regarding the ecological values of the surrounding area, resulting in high levels of erosion and increased vulnerability, given the exposure of many urban developments situated in floodable areas. Third, the environmental system is underpinned by a weakened and diminished Natural Park, due to the inundations which are and will be more recurrent, without interruption. The climate crisis generates a new urban, environmental and socioeconomic system and hence a new territorial planning.

Faced with this context of territorial fragility, regional and subregional plans should set out the guidelines to follow to prevent or in any case reduce the conditions resulting from climate crisis (Karl et al., 2009). To this must be added the insufficient cooperation between public and private bodies, the lack of interest in changes occurring in the Natural Park, the lack of citizen participation and the poor coordination between environmental planning and urban planning (Chica, 2010).

The climate crisis, as an undeniable fact, is the pillar on which any territorial planning must be grounded, especially when involving a littoral environment. Mitigation and adaptation are crucial for preventing and reducing its effects. Although the government is in charge of establishing intervention guidelines and disseminating the respective strategies, it stands to reason that the responsibility must be shouldered by each individual of society. The human being can modify the values of danger, exposure and vulnerability of its causes and impacts, as is already being done in many places. In Spain and therefore in the Bay of Cádiz, policies that are solely mitigating are being applied, as in the recent expansion of the urban bicycle network. However, the adaptation is still very rudimentary and cannot even be glimpsed in local political agendas.

The projections produced for this article were shown to various environmental officials of the Bay of Cádiz and experts in matters involving geography, territorial planning and sea sciences who have worked in the respective study context. The studies on mean sea-level rise presented in this paper open the doors to new and necessary research about the territorial conditions of the littoral environment of the Bay of Cádiz. Based on this methodology, such studies can also be conducted for other littoral environments with similar features. Study of the projections regarding the new climate reality is necessary and should be implemented in any kind of planning, whether territorial or urban and especially in littoral environments, by estimating the advance of waters caused by the rise of mean sea level.

\section{References}

Banholzer, S. Kosssin, J., Donner, S. 2014. The Impact of Climate Change on Natural Disasters. In: A. Singh, Z. Zommers (Eds.), Reducing Disaster: Early Warning Systems For Climate Change. Springer, Dordrecht pp. 21-49.

Benavente, J., Bello, E., Anfuso, G., Nachie, D., Macías, A. 2019. Sobreelevación debida a temporales y cambios producidos en las playas del litoral NE marroquí. Cuaternario y Geomorfología 21, 13-25. https://recyt.fecyt.es/index.php/CUGEO/article/view/16978

Benavente, J., del Río, L., Gracia, F.J. 2015. Riesgos de erosión costera en el litoral de Cádiz: Problemática actual y perspectivas futuras. Collectanea 204, 65-91. https://bit.ly/3jP4Caj 
Bornman, T.G., Schmidt, J., Adams, J.B., Mfikili, A.N., Farre, R.E., Smit, A.J. 2016. Relative sea-level rise and the potential for subsidence of the Swartkops Estuary intertidal salt marshes, South Africa. South African Journal of Botany 107, 91-100. https://doi.org/10.1016/j.sajb.2016.05.003

Bozhinova, D., van der Molen, M.K., van der Velde, I.R., Krol, M.C., van der Laan, S., Meijer, H.A.J., Peters, W. 2014. Simulating the integrated summertime $\Delta^{14} \mathrm{CO}_{2}$ signature from anthropogenic emissions over Western Europe. Atmospheric Chemistry and Physics 14, 7273-7290. https://doi.org/10.5194/acp-14$7273-2014$

Chica Ruiz, J.A., Barragán Muñoz, J.M. 2011. Estado y tendencia de los servicios de los ecosistemas litorales de Andalucía. Consejería de Medio Ambiente, Cádiz, 112 pp. https://bit.ly/2P31Anf

Chica Ruiz, J. A. 2010. Cambio climático y gestión costera en España. Un análisis de instrumentos. In: E. RiveraArriaga, I. Azuz-Adeath, L. Alpuche Gual, G. J. Villalobos-Zapata (Eds.), Cambio climático en México: un enfoque costero y marino. Universidad Autónoma de Campeche CTYS-Universidad, Campeche, pp. 773-787. https://bit.ly/2CWzKnM

Church, J.A., White, N.J. 2011. Sea-Level Rise from the Late 19th to the Early 21 st Century. Surveys in Geophysics 32, 585-602. https://doi.org/10.1007/s10712-011-9119-1

Clarcke, L.E., Edmonds, J., Jacoby, H., Pitcher, H., Reilly, J. 2007. Scenarios of Greenhouse Gas Emissions and Atmo-spheric Concentrations. US Department of Energy Publications, Lincoln, 166 pp.

Craft, C., Clough, J., Ehman, J., Joye, S. Park, R., Pennings, S. Guo, H., Machmuller, M. 2009. Forecasting the effects of accelerated sea-level rise on tidal marsh ecosystem services. Frontiers in Ecology and the Environment 7(2), 73-78. https://doi.org/10.1890/070219

CSIRO 2013. Reconstructed GMSL from 1880 to 2013. Available at: http://www.cmar.csiro.au/sealevel/sl_data_cmar.html (last access: 20/04/2019).

Echavarren, J.M., Balžekienè, A., Telešienė, A. 2019. Multilevel analysis of climate change risk perception in Europe: Natural hazards, political contexts and mediating individual effects. Safety Science 120, 813-823. https://doi.org/10.1016/j.ssci.2019.08.024

ESRI 2010. GIS for Climate Change. ESRI, New York, 53 pp.

FAO 2005. La ordenación integrada de zonas costeras (OIZC) y el sector forestal. Available at: http://www.fao.org/forestry/icam/es/ (last access: 13/07/2020).

FitzGerald, D.M., Fenster, M.S., Argow, B. A., Buynevich, I.V. 2008. Coastal Impacts Due to Sea-Level Rise. Annual Reviews Elanet Sciences https://doi.org/10.1146/annurev.earth.35.031306.140139

FOESA (2013). Cambio climático y acuicultura. FOESA, Madrid, España. 210 pp. https://bit.ly/39CY22c

Fraile Jurado, P., Álvarez Francoso, J., Ojeda Zújar, J. 2018. Cartografía de la probabilidad de inundación del litoral andaluz a finales del siglo XXI ante la subida del nivel del mar. Cuadernos Geográficos 57(2), 626. http://doi.org/10.30827/cuadgeo.v57i2.5899

Fraile Jurado, P., Álvarez Francoso, J., Sánchez Carnero, N., Ojeda Zújar, J. 2013. Análisis comparativo de la exposición a la subida del nivel medio del mar de la playa y marismas de Valdelagrana (Cádiz). GeoTemas 14, 167-170. https://bit.ly/3f5FkBb

Fraile Jurado, P., Fernández Díaz, M. 2016. Escenarios de subida del nivel medio del mar en los mareógrafos de las costas peninsulares de España en el año 2100. Estudios Geográficos 77(280), 57-79. https://doi.org/10.3989/estgeogr.201603

Fundéu 2019. Calentamiento global y cambio, crisis y emergencia climática. Available at: https://bit.ly/2DpDI8j (last access: 26/07/2020).

Gesch, D.B. 2009. Analysis of Lidar Elevation Data for Improved Identification and Delineation of Lands Vulnerable to Sea-Level Rise. Journal of Coastal Research 53, 49-58. https://doi.org/10.2112/SI53-006.1

Gómez Ferrer, A. 2011. Un espacio natural al ritmo de la marea. In: A. Gómez Ferrer et al., El Parque Natural Bahía de Cádiz, donde las mareas funden tierra y mar. Consejería de Medio Ambiente, Sevilla, pp. 5-9. 
Hartig, E. K., Gornitz, V., Kolker, A., Mushacke, F., Fallon, D. 2002. Anthropogenic and climate-change impacts on salt marshes of Jamaica Bay, New York City. Wetlands 22(1), 71-89. https://doi.org/10.1672/02775212(2002)022[0071:AACCIO]2.0.CO;2

Huaico Malhue, A.I., Romero Díaz, A., Espejel Carbajal, M.I. 2018. Evolución de los enfoques en desertificación: una revisión de 170 estudios de casos. Cuadernos Geográficos 57(2), 53-71. 10.30827/cuadgeo.v57i2.5530

IECA 2008. Modelo Digital de Andalucía 10 metros/pixel (2008 - 2009). Available at: https://bit.ly/2Utcwu3 (last access: 29/07/2020).

IECA 2016. Ortofotografía en Color 0.25-0.5 metros/pixel. Available at: https://bit.ly/2Utcwu3 (last access: 29/07/2020).

IECA 2019. Datos Espaciales de Referencia de Andalucía. Available at: https://bit.ly/3jIMKhr (last access: 29/07/2020).

Karl, T.R., Melillo, J.M., Peterson, T.C., Hassol, S.J. 2009. Global Climate Change Impacts in the United States. Cambridge University Press, Nueva York, 196 pp. http://aquaticcommons.org/2263/1/climate-impactsreport.pdf

Kulp, S.A., Strauss, B.H. 2019. New elevation data triple estimates of global vulnerability to sea-level rise and coastal flooding. Nature communications 10. https://doi.org/10.1038/s41467-019-12808-z

Le Roy Ladurie, E. 2017. Historia humana y comparada del clima. Fondo de la Cultura Económica, México D. F., 1087 pp.

MAPAMA 2016. Estrategia de Adaptación al Cambio Climático de la Costa Española. Dirección General de Sostenibilidad de la Costa y del Mar, Madrid, 120 pp.

Marletto, V., Johansson, H., Petersson Max, A., Prouteau, E., Brulfert, G., Chapuis, D., Chaxel, E., Girerd, I., Fritzsche, A., Röser, K., Schucht, M., Klementowski, P. 2012. Climate change planning for regional and local authorities. Regional Printing Centre of Emilia-Romagna, Bologna, 96 pp.

Masson-Delmotte, V., Zhai, P., Pörtner, H.O., Roberts, D., Skea, J., Shukla, P.R. (Co-Chairs). 2018. Global Warming of $1.5^{\circ} \mathrm{C}$. IPCC, Ginebra. https://bit.ly/39BpsVQ

Méndez Jiménez, M., Ceacero, C.J., Ordoñez, P., Guerrero Alvárez, J.J., Alvárez Peláez, S., Mesas Robles, A.I., Ojeda, J., Alvárez Francoso, J.I., Martín Cajaraville, D., Fraile-Jurado, P., Vallejo, I., Márquez, J. 2011. Análisis preliminar de la vulnerabilidad de la costa de Andalucía a la potencial subida del nivel del mar asociado al cambio climático. Consejería de Medio Ambiente, Sevilla, 154 pp. https://bit.ly/30VAfGD

ONU 2015. Acuerdo de París. Secretaria General de las Naciones Unidas, Nueva York, 29 pp. https://bit.ly/2Cn9odN

Paglia, E. 2018. The Socio-scientific Construction of Global Climate Crisis. Geopolitics 23(1), 96-123. https://doi.org/10.1080/14650045.2017.1328407

PE 2019. Datos históricos de la temperatura del agua. Available at: https://bit.ly/2X3ugOO (last access: 25/04/2019).

Pfeffer, W.T., Harper J. T., O’Neel, S. 2008. Kinematic con-straints on glacier contributions to 21st-century sealevel rise. Science 321, 1340-1343. https://doi.org/10.1126/science.1159099

Pissolito, C. A. 2019. Las consecuencias del cambio climático global en el ordenamiento territorial de Luján de Cuyo. Espacio Estratégico, Luján de Cuyo, 8 pp. https://bit.ly/30YnniW

Pongiglione, F. 2012. The key role of causal explanation in the climate change issue. Theoria 74, 175-188. https://doi.org/10.1387/theoria.3342

Prado, P., Alcaraz, C., Benito, X., Caiola, N., Ibáñez, C. 2019. Pristine vs. human-altered Ebro Delta habitats display contrasting resilience to RSLR. Science of the Total Environment 655, 1376-1386. https://doi.org/10.1016/j.scitotenv.2018.11.318

Pranzini, E., Williams, A. 2013. Coastal Erosion and Protection in Europe. Routledge, London, 488 pp.

PSMSL 2019. Mareógrafo Cádiz III. Available at: https://bit.ly/39zG6oQ (last access: 4/04/2019). 
Raw, J.L., Riddin, T., Wasserman, J., Lehman, T.W.K., Bornman, T.G., Adams, J.B. 2020. Salt marsh elevation and responses to future sea-level rise in the Knysna Estuary, South Africa. African Journal of Aquatic Science 45(1-2), 49-64. https://doi.org/10.2989/16085914.2019.1662763

Reed, D.J. 2002. Sea-level rise and coastal marsh sustaintability: geological and ecological factors in the Mississippi delta plain. Geomorphology 48, 233-243. https://doi.org/10.1016/S0169-555X(02)00183-6

Rendón Vega, J.L. 2011. La vegetación de las marismas y salinas. In: A. Gómez Ferrer et al., El Parque Natural Bahía de Cádiz, donde las mareas funden tierra y mar. Consejería de Medio Ambiente, Sevilla, pp. $45-$ 54.

Rodríguez, G. 2015. Red Natura 2000, parte de la solución para la adaptación al cambio climático. In: A. Herrero Méndez, M. A. de Zavala Gironés (Eds.), Los bosques y la biodiversidad frente al cambio climático. Ministerio de Agricultura, Alimentación y Medio Ambiente, Madrid, pp. 457-461.

Spencer, T., Brooks, S.M., Evans, B.R., Tempest, J.A., Möller, I. 2015. Southern North Sea storm surge event of 5 December 2013: Water levels, waves and coastal impacts. Earth-Science Reviews 146, 120-145. https://doi.org/10.1016/j.earscirev.2015.04.002

Stocker, T.F., Qin, D. (Co-Chairs). 2013. Cambio Climático 2013: Bases físicas. Resumen para responsables de politicas, Resumen técnico y Preguntas frecuentes. IPCC, Ginebra, 222 pp.

Thiéblemont, R., Le Cozannet, G., Toimil, A., Meyssignac, B., Losada, I.J. 2019. Likely and high-end impacts of regional sea-level rise on the shoreline change of European sandy coasts under a high greenhouse gas emissions scenario. Water 11(12), 2607. https://doi.org/10.3390/w11122607

Titus, J.G., Richman, C. 2001. Maps of lands vulnerable to sea level rise: Modeled elevations along the US Atlantic and Gulf coasts. Inter-Research Science Publisher 18, 205-228. https://doi.org/10.3354/cr018205

Trischler, H. 2017. El Antropoceno, ¿un concepto geológico o cultural, o ambos? Desacatos 54, 40-57. https://doi.org/10.29340/54.1739

Valladares, F., Magro, S., Martín-Forés, I. 2019. Antropocene, the challenge for Homo sapiens to set its own limits. Cuadernos de Investigación Geográfica 45(1), 33-59. http://doi.org/10.18172/cig.3681

Van Khanh Triet, N., Viet Dung, N., Phi Hoang, L., Le Duy, N., Duc Tran, D., Tuan Anh, T., Kummu, M., Merz, B., Apel, H. 2020. Future projections of flood dynamics in the Vietnamese Mekong Delta. Science of the Total Environment 742, 1-13. https://doi.org/10.1016/j.scitotenv.2020.140596

Vineis, P., Khan, A., D’Abramo, F. 2011. Epistemological issues raised by research on climate change. In: P. M. Illari, F. Russo, Williamson, J. (Eds.), Causality in the Sciences. Oxford University Press, Oxford, pp. 493-501. https://doi.org/10.1093/acprof:oso/9780199574131.003.0023

Vousdoukas, M.I., Mentaschi, L., Hinkel, J., Ward, P.J., Mongelli, I., Ciscar, J.C., Feyen, L. 2020. Economic motivation for raising coastal flood defenses in Europe. Nature Communications 11, 2119. https://doi.org/10.1038/s41467-020-15665-3

WHO 2012. Regional strategy for protecting health from climate change. Regional Office for South-East Asia, New Delhi, 87 pp.

Wigand, C., Ardito, T., Chaffee, C., Ferguson, W., Paton, S., Raposa, K., Vandemoer, C., Watson, E. 2015. A Climate Change Adaptation Strategy for Management of Coastal Marsh Systems. Estuaries and Coasts 40, 682-693. https://doi.org/10.1007/s12237-015-0003-y 